\title{
BEPS principal purpose test and customary international law
}

\author{
Irma Johanna Mosquera Valderrama ${ }^{1}$ (D) \\ Leiden University, Steenschuur 25, 2311ES Leiden, Netherlands \\ Email: i.j.mosquera.valderrama@law.leidenuniv.nl
}

\begin{abstract}
The overall aim of this article is to analyse the principal purpose test as an emerging rule of customary international tax law. By means of the principal purpose test, the tax administration can deny the tax treaty benefit if one of the principal purposes of the action undertaken by the taxpayer was to obtain a benefit. This principal purpose test has been developed by the OECD with the political support of the G20 as one of the actions to tackle Base Erosion and Profit Shifting by multinationals (BEPS Project). At the time of writing, 137 jurisdictions including non-OECD, non-G-20 countries have committed to the implementation of the principal purpose test in their current and future tax treaties. Based on the analysis of the objective element (state practice) and subjective element (accepted as law), there are indications that this principal purpose test can emerge as a principle of customary international law. In the past, international tax law scholars addressed the customary international law regarding the OECD/UN tax treaty Models, the OECD Harmful Tax Practices, and the arm's length principle. However, current international tax developments, including the BEPS Project, call for an analysis of the main elements of customary international law in respect of the principal purpose test, a general anti-avoidance rule that by its own nature, is often general, vague, and imprecise. Therefore, the findings of this article can be useful for generating new areas of research by international public law, international law, and international tax law experts.
\end{abstract}

Keywords: BEPS and aggressive tax planning; customary international law; international tax law; principal purpose test; tax interpretation

\section{Introduction}

In 2013, the Organisation for Economic Cooperation and Development (OECD) with the political mandate of the G20 introduced the Base Erosion and Profit Shifting (BEPS) Project to prevent profit shifting by multinationals. ${ }^{2}$ Later, in 2015, the OECD presented 15 Actions to tackle BEPS including a proposal to introduce a multilateral convention (MLI) to enable countries to

\footnotetext{
${ }^{1}$ Associate Professor of Tax Law in the Institute of Tax Law and Economics, Faculty of Law at the University of Leiden in the Netherlands and Principal Investigator for the ERC Grant GLOBTAXGOV Project: A New Model of Global Governance in International Tax Law Making. The writing and research carried out for this article is the result of the ERC research in the framework of the GLOBTAXGOV Project (2018-2023). This Project investigates international tax law making, including the adoption of OECD and EU standards by 12 countries. See GLOBTAXGOV, available at globtaxgov.weblog.leidenuniv.nl/.

The GLOBTAXGOV Project has received funding from the European Research Council (ERC) under the European Union's Seven Framework Programme (FP/2007-2013) (ERC Grant agreement n. 758671). An early version of this article was presented at the Workshop Customary International Law and its Interpretation in International Tax \& Investment Law. This workshop was organized by the ERC Projects: TRICI-LAW which principal investigator is Prof. Panos Merkouris at the University of Groningen researching on 'The Rules of Interpretation of Customary International Law' in co-operation with GLOBTAXGOV. The author is grateful for the feedback provided by the discussants and participants at this workshop.

${ }^{2}$ See www.oecd.org/tax/beps/. 
streamline the implementation of the BEPS treaty measures (Action 15). ${ }^{3}$ The content of these 15 Actions was decided by the BEPS 44 group (G20, OECD, and OECD accession (at that time) ${ }^{4}$ countries).

In June 2016, representatives of more than 80 countries gathered in Kyoto, Japan, to push the BEPS Project forward by creating the BEPS Inclusive Framework with the OECD having the role of secretariat. ${ }^{5}$ In this framework, countries committed to implementation on an equal footing of the BEPS Four Minimum Standards that deal with harmful tax competition, tax treaty abuse, transfer pricing documentation, and dispute resolution (Actions 5, 6, 13, and 14). At the time of writing, 137 jurisdictions have committed to the implementation of these standards. ${ }^{6}$

Furthermore, in June 2017, more than 70 jurisdictions signed the OECD Multilateral Convention to Implement Tax Treaty Related Measures to Prevent Base Erosion and Profit Shifting (the MLI). The MLI modifies bilateral tax treaties with regard to some of the BEPS Actions, including two of the four minimum standards (Actions 6 and 14). At the time of writing, 93 jurisdictions have signed the MLI (of which 33 have ratified and more are expected to ratify). This MLI entered into force as of 1 July $2018 .^{8}$

One of the minimum standards included in the BEPS Inclusive Framework and in the MLI is Action 6, introduced with the aim to tackle treaty abuse (and also includes treaty shopping). ${ }^{9}$ BEPS Action 6 introduced a preamble ${ }^{10}$ and a treaty provision that will take one of the following three forms: (i) Principal purpose test; (ii) Principal purpose test with either a simplified or detailed limitation on benefits provisions; and (iii) a detailed limitation-on-benefits (LOB) with anti-abuse measures to counteract conduit financing. ${ }^{11}$

Since the principal purpose test has been adopted by most of the countries, i.e., 136 of the 137 jurisdictions of the BEPS Inclusive Framework, and one country (Cyprus) which is only a signatory of the MLI but has not committed to the BEPS Inclusive Framework, it is safe to argue that this standard will be widely applied by G20/OECD and non-OECD/non-G20 countries

\footnotetext{
${ }^{3}$ See www.oecd.org/tax/beps/beps-actions.htm.

${ }^{4}$ The OECD accession countries at that time were Colombia and Latvia. Since then, Latvia has become a full member of the OECD and Colombia is in the process of formalization of OECD membership. See www.oecd.org/about/membersandpartners/ and www.oecd.org/about/secretary-general/signing-ceremony-of-oecd-accession-agreement-with-colombia-and-lithuania-france30-may-2018.htm.

${ }^{5}$ The OECD Secretariat is located in Paris and supports the activities of the OECD Committees existing in several areas including economic, trade, development, and tax. For the BEPS Inclusive Framework the OECD Secretariat will support their activities.

${ }^{6}$ www.oecd.org/ctp/beps/inclusive-framework-on-beps-composition.pdf.

${ }^{7}$ The countries that have signed the MLI are all (except one) members of the BEPS Inclusive Framework. Cyprus is the only country that is not a member of the BEPS Inclusive Framework. See www.oecd.org/tax/treaties/beps-mli-signatories-andparties.pdf.

${ }^{8}$ The MLI entered into force following the deposit of the $5^{\text {th }}$ country instrument of ratification. The first five countries were Slovenia, Austria, the Isle of Man, Jersey, and Poland.

${ }^{9}$ According to the FAQ OECD 'Treaty shopping' generally refers to arrangements through which a person who is not a resident of one of the two states that concluded a tax treaty may attempt to obtain benefits that the treaty grants to residents of these states. These strategies are often implemented by establishing companies in states with desirable tax treaties that are often qualified as 'letterboxes', 'shell companies', or 'conduits' because these companies exist on paper but have no or hardly any substance in reality. See www.oecd.org/tax/beps/beps-frequentlyaskedquestions.htm\#Action6.

${ }^{10}$ The preamble states, 'Intending to conclude a Convention for the elimination of double taxation with respect to taxes on income and on capital without creating opportunities for non-taxation or reduced taxation through tax evasion or avoidance (including treaty shopping arrangements aimed at obtaining reliefs provided in this Convention for the indirect benefit of residents of third states).'

${ }^{11}$ The terms of reference for peer review of Action 6 refers to 'a mechanism (such as a treaty rule that might take the form of a PPT rule restricted to conduit arrangements, or domestic anti-abuse rules or judicial doctrines that would achieve a similar result) that would deal with conduit arrangements not already dealt with in tax treaties'. OECD (2017), BEPS Action 6 on Preventing the Granting of Treaty Benefits in Inappropriate Circumstances - Peer Review Documents, OECD/G20 Base Erosion and Profit Shifting Project, OECD, Paris, available at www.oecd.org/tax/treaties/beps-action-6-preventing-the-granting-oftreaty-benefits-in-inappropriate-circumstance-peer-review-documents.pdf, at 11.
} 
committed either to the BEPS Inclusive Framework and/or MLI. At the time of writing, the United States is the only country of the BEPS Inclusive Framework that has not adopted the principal purpose test and, instead, has chosen option (iii) above. ${ }^{12}$

In light of this wide application and acceptance by countries around the world, including non-OECD/non-G20 countries, the focus in this article will be on the principal purpose test as a rule of customary international law. By means of the principal purpose test, the tax administration can deny the tax treaty benefit if one of the principal purposes of the action undertaken by the taxpayer was to obtain a tax benefit. ${ }^{13}$

This article aims to answer the following question: Is the widespread practice of including a principal purpose test in tax treaties enough to create a customary international tax law rule? In order to answer this question, this article is structured as follows. Section 2 will first address the main elements of customary international law as developed by the 2000 Report of the International Law Association (ILA) and the 2018 UN International Law Commission (ILC) in Section 2.1. ${ }^{14}$ Thereafter, in Section 2.2, a short reference to the study of international customary law in tax law will be presented. Subsequently, in light of the main elements of international customary law described in Section 2, the analysis of the principal purpose test as a rule of customary international tax law will be presented in Section 3. Section 4 will conclude.

\section{Customary international law and international tax law}

\subsection{Customary international law}

The ILA stated that a:

rule of customary international law is one which is created and sustained by the constant and uniform practice of States and other subjects of international law in or impinging upon their international legal relations, in circumstances which give rise to a legitimate expectation of similar conduct in the future. ${ }^{15}$

\footnotetext{
${ }^{12}$ As stated in the peer review report of Action 6 (March 2019), 'the United States expects to comply with the minimum standard through a detailed LOB which is not available through the MLI. Therefore, the United States did not sign the MLI and will implement the minimum standard bilaterally'. See OECD (2019), Prevention of Treaty Abuse - Peer Review Report on Treaty Shopping: Inclusive Framework on BEPS: Action 6, OECD/G20 Base Erosion and Profit Shifting Project, OECD Publishing, Paris, available at doi.org/10.1787/9789264312388-en, at 249. After finalizing this article, a new peer review report was published (March 2020). According to the OECD, this second peer review report reveals that a large majority of members of the OECD/G20 Inclusive Framework on BEPS (IF) are translating their commitment on treaty shopping into actions and are modifying their treaty network. The report includes the aggregate results of the peer review and data on tax treaties concluded by each of the 129 jurisdictions that were IF members on 30 June 2019. The data of this second peer review report has not been analysed in this article. However, since most of the countries (except the United States) are following the principle purpose test, the findings of this article can also be useful to analyse this second peer review report. OECD (2020), Prevention of Treaty Abuse - Second Peer Review Report on Treaty Shopping, OECD, Paris. See www.oecd.org/tax/beps/prevention-oftreaty-abuse-second-peer-review-report-on-treaty-shopping.pdf.

${ }^{13}$ Cf. Section 3.1 infra.

${ }^{14}$ In addition to the cases by the International Court of Justice (ICJ), there are two documents that contain a definition and elements of customary international law. These are International Law Association, London Conference, Final Report of Commission on Formation of Customary (General) International Law, Statement of Principles Applicable to the Formation of General Customary International Law (2000), [hereinafter ILA report], available at perma.cc/5CJ8-UTR2; and International Law Commission, Identification of Customary International Law, UN Doc. A/73/10 (2018), Draft Conclusions and Commentaries Adopted by the General Assembly on 20 December 2018. UN Doc. A/RES/73/203 (2018), [hereinafter ILC report], available at legal.un.org/docs/?symbol=A/RES/73/203.

${ }^{15}$ ILA Final Report, ibid., at 8.
} 
Notwithstanding this definition, the definition and legal character of customary international law has also received criticism from international law scholars. ${ }^{16}$ For instance, Trachtman has argued that 'customary international law is obsolete and cannot respond effectively to the challenges of modern society. ${ }^{17}$ In addition, for Trachtman, due to:

[t]he complex arrangements for mutual deference under bilateral tax treaties, it is difficult to imagine these varied and complex arrangements arising from and becoming empirically identifiable under a CIL regime. There are so many details and contingencies, conditions, and exceptions that it would be difficult to identify the custom. ${ }^{18}$

Another scholar, Lepard, while recognizing the existence and use of customary international law, also addressed the need for a new normative framework of customary international law. This normative framework 'must provide an account of why certain norms should be treated as "authoritative" and "law". ${ }^{19}$ The work of Trachtman and Lepard can contribute to creating a new framework of customary international law that takes into account the use of treaties and the requirement of participation in a global community of states. ${ }^{20}$ This framework is outside of the scope of this contribution. ${ }^{21}$

Notwithstanding these different views, in general, the use and existence of customary international law has been widely recognized by scholars, countries, and courts (ICJ), and, therefore, the starting point of this article is that there is customary international law that is recognized as one of the sources of international law according to Article 38(1)(b) ICJ Statute.

\subsection{Elements to create customary international law}

In general, scholars and courts have referred to two elements to create customary international law which are the objective element (state practice: uniform, extensive, representative, and consistent $^{22}$ ) and the subjective element (accepted by law opinio juris). ${ }^{23}$ Nevertheless, the emphasis placed on these elements can be different. For instance, the UN ILC states that 'determining a rule of customary international law requires establishing the existence of two constituent elements: a general practice, and acceptance as law (opinio juris)' ${ }^{24}$

\footnotetext{
${ }^{16}$ Also, a tax scholar has referred to the criticism by international law scholars of the (assumed) binding character of customary international law. See P. Hongler, Justice in International Tax Law: A Normative Review of the International Tax Regime (2019), at 141-7.

${ }^{17}$ Early article by J. Trachtman, 'The Obsolence of Customary International Law', SSRN, 16 November 2014, available at ssrn.com/abstract $=2512757$.

${ }^{18}$ See J. Trachtman, 'The Growing Obsolescence of Customary International Law', in C. Bradley (ed.), Custom's Future: International Law in a Changing World (2016), 172.

${ }^{19}$ B. Lepard, Customary International Law: A New Theory with Practical Applications (2010), at 11.

${ }^{20}$ Lepard stated that the 'recognition of the existence of a community of states indicates that each state ought to abide by norms that state as well as the requirement for the members generally believe ought to be authoritative, so long as the norms help to implement fundamental ethical principles, or are at least consistent with them and do not directly contravene them'. Ibid., at 101.

${ }^{21}$ In tax law, Hongler, following Trachtman, has argued the limitations of customary international law. See Hongler, supra note 16 , at $160-5$.

${ }^{22}$ While the ILA refers to uniform, extensive, and representative, the ILC also referred to consistency as a fourth criterion. See ILC Report UN Doc. A/73/10 (2018), supra note 14, at 235. See also Section 2.1.1 infra.

${ }^{23}$ See Art. 38(1) ICJ Statute referring to the application by the ICJ of International custom, as evidence of a general practice accepted as law to international law disputes. The landmark case for these two elements is the North Sea Continental Shelf case between the Federal Republic of Germany and the Kingdom of Denmark; and between the Republic of Germany and the Kingdom of the Netherlands (Germany v. Denmark and Germany v. the Netherlands), Judgment of 20 February 1969 , [1969] ICJ Rep. 1969, 3. See also D. M. Bodansky, 'The Concept of Customary International Law', (1995) 16 Mich. J. Int'l L., at 667.

${ }^{24}$ ILC Report UN Doc. A/73/10 (2018), supra note 14, at 124.
} 
However, such an approach has not gone uncontested. See, for instance, the ILA, which considers that it is not usually necessary to demonstrate the existence of the subject element before a customary rule can be said to have come into being' ${ }^{25}$ For the ILA, the main point is that it is not necessary for an individual state to have consent (still less, to be proved to have consented) to a rule for it to be bound, provided the other conditions in Part II are satisfied'. ${ }^{26}$ These two elements and the differences in approach regarding the subjective element will be explained below.

\subsubsection{Objective element: State practice}

In respect of the objective element, the ILA states that for a customary international law to exist, what is required is state practice, that results in a sufficient extensive and representative number of states participating in such a practice in a consistent manner. ${ }^{27}$ Furthermore, the ILA indicates that customary international law results from the actions of the states in their international legal relations, and it does not stop when the rule has emerged but is a continuing process. ${ }^{28}$ The ILC states that the requirement of general practice, 'refers primarily to the practice of States that contributes to the formation, or expression, of rules of customary international law'. ${ }^{29}$

The ILA posits that, for state practice to create customary international law, the practice should be uniform, extensive, and representative in character. The ILC refers to the three elements of the ILA and also includes the criterion of consistency. ${ }^{30}$ These elements of state practice have been developed by the ICJ in several cases. For instance:

a) Uniformity: The ICJ stated in the Asylum case and the Fisheries case $\mathrm{e}^{31}$ that uniformity of the state practice should be internal and collective. For the ILA internal uniformity means that each state whose behavior is being considered should have acted in the same way on virtually all of the occasions on which is engaged in the practice in question. Collective uniformity means that different states must not have engaged in substantially different conduct, some doing one thing and some another'; ${ }^{32}$

b) Consistency: In the Nicaragua case, the ICJ stated that in order to deduce the existence of customary rules, the Court deems it sufficient that the conduct of states should in general be consistent with such a rule; and that instances of state conduct inconsistent with a given rule should generally have been treated as breaches of that rule, not as indications of the recognition of a new rule'; ${ }^{33}$

c) Widespread and representative: The ICJ in the North Sea Continental Shelf cases stated that these requirements refer to the acceptance by a majority of states of the emerging customary rule. This acceptance does not refer to a specific percentage, and it does not need to be universal. $^{34}$

\footnotetext{
${ }^{25}$ ILA Final Report, supra note 14, at 10.

${ }^{26}$ Part II in the ILA 2000 referred to state practice. Ibid., at 31.

${ }^{27}$ Ibid., at 8 .

${ }^{28}$ Ibid., at 9.

${ }^{29}$ ILC Report UN Doc. A/73/10 (2018), supra note 14, at 130.

${ }^{30}$ Ibid., at 135 .

${ }^{31}$ Asylum case between the Republic of Colombia and the Republic of Peru (Colombia v. Peru), Judgment of 20 November 1950, ICJ Rep. 1950, 266; Fisheries case between the United Kingdom of Great Britain and Northern Ireland and Kingdom of Norway (United Kingdom and Northern Ireland v. Norway), Judgment of 18 December 1951, ICJ Rep. $1951,116$.

${ }^{32}$ ILA Final Report, supra note 14, at 21.

${ }^{33}$ Case Concerning Military and Paramilitary Activities in and Against Nicaragua between the Republic of Nicaragua and the United States of America (Nicaragua v. USA), Judgment of 25 June 1986, ICJ Rep. 1986, 14.

${ }^{34}$ ILA Final Report referring also to the North Sea Continental Shelf Cases stating that 'given the inherently informal nature of customary law, it is not to be expected, neither is it, the case, that a precise number of percentage of States is required. Much will depend on circumstances, and, in particular, on the degree of representativeness of the practice'. See ILA Final Report, supra note 14 , at 25 .
} 
One of the issues that has also been raised by scholars is the amount of time that it takes before a practice emerges as customary international law. However, to a great extent, there is consensus between international law scholars that the duration can be relative, customary international law can be created even within a short timeframe. ${ }^{35}$

Two additional factors can influence the state practice, i.e., the persistent objector rule and the affected states doctrine. ${ }^{36}$ These two factors are explained below.

\subsubsection{Persistent objector rule. For the state practice to exist, a specific state should not have} persistent and open dissention from the rule since, in this case, such a state will not be bound by the customary law rule. This is the 'persistent objector rule' that is also introduced in ICJ case law. ${ }^{37}$ Accordingly, any state can, by its persistent objection, 'prevent an emerging rule of customary law'. ${ }^{38}$ However, the persistent objector rule 'applies only when the customary rule is in the process of emerging. It does not, therefore, benefit states which came into existence only after the rule matured, or which became involved in the activity in question only at a later stage'. ${ }^{39}$ Nevertheless, there is still uncertainty in scholarship how the persistent objector rule is applied by the ICJ. ${ }^{40}$

2.2.1.2 Affected States Doctrine. The affected states doctrine was first addressed by the ICJ in the North Sea Continental Shelf cases stating that 'a very widespread and representative participation in the convention might suffice of itself, provided it included that of States whose interests were specially affected'. ${ }^{41}$ However, there is no clarity in the doctrine on what it means to be 'specially affected'. As rightly stated by Heller, countries such as the United States have relied on the 'ICJ's doctrine of specially-affected states to claim that it and other powerful states in the Global North play a privileged role in the formation of customary international law'. ${ }^{42}$

\subsubsection{Subjective element: Accepted as law}

Regarding the subjective element, the ILA states that:

the subjective element means, for some, consent or will that something be a rule of customary law and, for others a belief that it is a rule - to put it simply. It is possible to achieve an elision or apparent reconciliation of these two approaches by using such terms as "accepted" or "recognized" as law. These words can connote a mere acknowledgment of an existing state of affairs (a declaratory viewpoint), or they may bear a constitutive meaning - States are bound by the rule because they choose to acknowledge. ${ }^{43}$

\footnotetext{
${ }^{35}$ See Hongler, supra note 16 , at 148 , referring to Villiger who argues that 'most authors agree that customary international law can also be created within a short time frame and, therefore, the duration of a certain practice is a relative requirement'. M. E. Villiger, Customary International Law and Treaties (1997), 45.

${ }^{36}$ These two factors will be also addressed in respect of the principal purpose test in Section 3.2.1 infra.

${ }^{37}$ See Asylum case and Fisheries case, supra note 31.

${ }^{38}$ ILA Final Report, supra note 14, at 27.

${ }^{39}$ Ibid.

${ }^{40}$ For instance, in the Fisheries case, ICJ 1951, supra note 31, this doctrine was mentioned but not applied. In the Asylum case, the IJC mentioned the condition to apply the persistent objector rule only if the state objected during the emerging of the rule. There is not yet agreement in scholarship whether this doctrine is indeed in international judicial practice. See P. Dumberry, 'Incoherent and Ineffective: The Concept of Persistent Objector Revisited', (2010) 59 ICLQ 779; O. Elias, 'Some Remarks on the Persistent Objector Rule in Customary International Law', (1991) 6 Denning L.J. 37.

${ }^{41}$ North Sea Continental Shelf cases, supra note 23, para. 73, at 43.

${ }^{42}$ K. J. Heller. 'Specially Affected States and the Formation of Custom'. (2018) 112 AJIL 191, at 191. For the application of this doctrine in customary international tax law see Section 3.2.1 infra.

${ }^{43}$ ILA Final Report, supra note 14, at 30; and footnote 77 stating that, "[a]s it happens, "accepted as law" is the expression used in Article 38(1)(b) of the Statute of the ICJ'.
} 
As mentioned above, there are different interpretations of the importance of the subjective element by the ILA and the ILC. The ILC states that the subjective element is a constituent element of customary international law. Accordingly, 'establishing that a certain practice is followed consistently by a sufficient widespread and representative number of States does not in itself suffice in order to identify a rule of customary international law'. ${ }^{44}$ Therefore, the second constituent element of customary international law, sometimes referred to as the 'subjective' or 'psychological' element, requires that, in each case, it is also necessary to be satisfied that there exists among States an acceptance as law (opinio juris) as to the binding character of the practice in question'. ${ }^{45}$

Another view is that of the ILA, stating that the most important requirement to be met for a rule to be considered customary international law is state practice. For the ILA, state practice is sufficient to bind a state to a corresponding rule of customary law; it is not necessary to prove that such consent has been given by a State for it to be bound by the rule in question, subject to Section $15{ }^{46}$ Neither is it necessary to provide the consent of the generality of the states. ${ }^{47}$ According to the ILA report, the main function of the subjective element (opinio juris sive necessitatis) ${ }^{48}$ is to indicate what practice counts (or more precisely does not count) towards the formation of a customary rule' ${ }^{49}$

Therefore, unlike the ILC, the subjective element for the ILA is not a constituent element to establish customary international law and, therefore, the requirements to be met are lower. ${ }^{50}$ Despite these differences in approach, since both reports are non-binding, it can be argued, in principle, that both reports have equal value. However, the ILC reports elaborated in the framework of the United Nations are more authoritative. ${ }^{51}$ The differences in approach are important for further analysis of international tax law as customary law. This analysis is provided in the following section.

\subsection{Tax Law and customary international law}

\subsubsection{Is there a customary international tax law?}

In 2004, a tax scholar, Avi-Yonah raised the question: is there a customary international tax law? ${ }^{52}$ For this author, in light of the international tax practices that are widely followed by countries, including the methods to prevent double taxation, and the use in the more than 2,000 bilateral tax

\footnotetext{
${ }^{44}$ ILC Report UN Doc. A/73/10 (2018), supra note 14, at 138.

${ }^{45}$ Ibid.

${ }^{46}$ Referring to the 'persistent objector rule'.

${ }^{47}$ ILA Final Report, supra note 14, at 38.

${ }^{48}$ The ILA Final Report when referring to this subjective element states that opinio juris sive necessitatis means literally 'belief of law or of necessity', and it (and especially its short form opinion juris) is probably best rendered by 'belief in the legal permissibility or (as the case may be) obligatoriness of the practice'. Ibid., at 33.

${ }^{49}$ Ibid., at 10 .

${ }^{50}$ Ibid., at 30 .

${ }^{51}$ In this regard, Wood in the ILC Annex when referring to the studies for the formation and evidence of customary international law states that 'given its composition and collegial working methods, and its close relationship with States through the General Assembly, may be able to make a useful contribution'. Therefore, the link to the United Nations General Assembly and the states' participation can provide more authority. M. Wood. 'Formation and Evidence of customary International law', in Report of the International Law Commission on the work of its sixty-third session, Annex I (2011), available at legal.un.org/ ilc/reports/2011/english/annex.pdf.

Unlike the ILC, the ILA is a non-profit organization that focus on 'the study, clarification and development of international law, both public and private, and the furtherance of international understanding and respect for international law'. The ILA has consultative status, as an international non-governmental organization, with a number of the United Nations specialized agencies; see www.ila-hq.org/index.php/about-us/aboutus2.

${ }^{52}$ R. S. Avi-Yonah, 'International Tax as International Law', (2004) 57 Tax L. Rev. 483.
} 
treaties (either UN or OECD model treaties), the question is whether these practices are enough to create customary international law. ${ }^{53}$

For the definition of customary international law, Avi-Yonah referred to the US Restatement (Third) of Foreign Relations Law (1987) stating that it is the law that results from a general and consistent practice of states followed by them from a sense of legal obligation'. ${ }^{54}$ The restatement further states that 'International Agreements create law for states parties thereto and may lead to the creation of customary international law when such agreements are intended for adherence by states generally and are in fact widely accepted' ${ }^{55}$ In addition, in light of the elements of customary international law, i.e., objective and subjective, this author states that the "hard question is whether countries not only follow a rule but do so out of a sense of legal obligation (opinio juris)' ${ }^{56}$

Avi-Yonah argued with some examples that 'an international tax regime does exist and that it rises to the level of customary international law'. The examples provided referred to (i) the spread of controlled foreign corporation (CFC) legislation that allows countries to tax non-residents on their foreign source income; (ii) the non-discrimination norm that is in tax treaties (Article 24) but also binding even in the absence of a treaty; (iii) the use of the arm's length standard to determine the proper allocation of profits between related entities; and (iv) the use of the credit or exemption method to prevent double taxation that is done even in the absence of a treaty. ${ }^{57}$

From the examples mentioned by Avi-Yonah, two elements are important, i.e., the adoption by states even in the absence of a treaty (objective element), ${ }^{58}$ and also that countries do so out of a sense of legal obligation (opinio juris) (subjective element). Therefore, this author argues, 'to the extent that customary international law exists, this suggests that it is a mistake to deny the existence of an international tax system or regime'. ${ }^{59}$ Finally this author concludes that in 'the United States, in the absence of treaties or legislation, resort can be made to customary international law'. ${ }^{60}$

Avi-Yonah's arguments are based on the United States perspective that is also shown by the use of the US Restatement (Third) of Foreign Relations Law (1987) and the analysis of the examples given from a US perspective: (i) jurisdiction to tax, (ii) the permanent establishment threshold, (iii) the arm's length standard, and (iv) non-discrimination. ${ }^{61}$

Even though the examples mentioned by Avi-Yonah are also useful for other countries around the world, the analysis of customary international law requires the worldwide analysis of the objective (state practice) and subjective (accepted as law) elements. In this case, examples (ii), (iii), and (iv) meet the requirement of state practice mainly due to the use of the OECD/UN Model Treaties and their commentaries, as well as the Transfer Pricing Guidelines ${ }^{62}$ by countries

\footnotetext{
${ }^{53}$ This analysis of Avi-Yonah follows the argument of another tax scholar (Rosenbloom) who denied the existence of an international tax regime since the network of bilateral tax treaties is optional (elective) and represents, 'a triumph of international law in the field of taxation'. Therefore, a 'taxpayer may reject a treaty and its contents and invoke instead its rights under domestic law, both in the United States and in the other country'. D. Rosenbloom, 'International Tax Arbitrage and the International Tax System: The David R. Tillinghast Lecture', (2000) 53 Tax L. Rev. 137, at 164.

${ }^{54}$ Restatement (Third) Foreign Relations Law $₫ 102(2)$.

${ }^{55}$ Ibid. $\$ 102(3)$.

${ }^{56}$ See Avi-Yonah, supra note 52, at 498.

${ }^{57}$ Ibid., at 499.

${ }^{58} \mathrm{Ibid}$. Avi-Yonah does not refer to consistency.

${ }^{59}$ Ibid., at 501 .

${ }^{60} \mathrm{Ibid}$. Treaty override can result in a fragmentation or diversification of international law. See paras. 58-97 addressing the problems of lex specialis and lex posteriori. International Law Commission, Fragmentation of International Law: Difficulties Arising from the Diversification and Expansion of International law, Report of the Study Group of the International Law Committee, UN doc A/CN.4/L.682 (2006), available at legal.un.org/ilc/documentation/english/a_cn4_1682.pdf.

${ }^{61}$ This US approach has been addressed by Avi-Yonah in a recent paper: R. S. Avi-Yonah, 'Does Customary International Tax Law Exist?', SSRN, 16 July 2019, available at papers.ssrn.com/sol3/papers.cfm?abstract_id=3382203.

${ }^{62}$ One exception in transfer pricing is Brazil which has adopted the comparable margins method which is different to the arm's length method. Since Brazil was not a member of the OECD at the time of adoption of the transfer pricing guidelines, the
} 
around the world. However, examples (ii), (iii), and (iv) do not meet the requirement of being accepted as law (opinio juris) since these rules are in model treaties/guidelines that countries may or may not decide to adopt. ${ }^{63}$

In the case of example (i), countries did not decide to introduce CFC rules until the adoption of the BEPS Project. Before 2013, the CFC rules did not meet the element of state practice since the number of countries introducing CFC rules was neither extensive nor representative. From the time of the adoption of the CFC rules (1963) until the time that BEPS Action 3 was published (2015), only 30 of the 193 countries around the world had adopted CFC legislation. ${ }^{64}$ Nevertheless, it is expected that with the introduction of BEPS Action 3, more countries will do so. However, since BEPS Action 3 is not regarded as a minimum standard for countries of the BEPS Inclusive Framework, the number of countries may be less than the 137 jurisdictions participating in the framework.

Furthermore, it is important to mention that the United States has taken a different approach regarding the use of international customary tax rules that can create issues with respect to the uniformity and consistency of state practice. For instance, even though the US initiated the use of the arm's length standard that relies on the use of comparables for its application and has been adopted by the OECD Transfer Pricing Guidelines and by countries in their tax treaties (Article 9), the United States decided to follow a different path as shown with two examples. The first is the introduction by the United States of two methods for which comparables do not have an important role or any role at all. ${ }^{65}$ The second is the use of the formula appointment that is a non-arm's length method. The United States Supreme Court has also upheld the use of the formula apportionment. ${ }^{66}$ Hence, the result is lack of uniformity and consistency.

The use and interpretation of international customary law rules in the United States can have a different connotation than in other countries, where, unlike the United States, there is no tax treaty override. Since domestic legislation in the United States can override treaties or customary international law, the application of the arm's length principle will not be the same as the one that is applicable in the tax treaties or in the customary international law.

\subsubsection{Harmful (soft law) tax practices as customary international law?}

Another tax scholar addressing the use of customary international law in respect of the OECD's Report on Harmful Tax Practices ${ }^{67}$ is Christians, who refers to hard law vs. soft law in international taxation. For this author:

the use by tax scholars of these terms raises the specter of whether and to what extent international tax norms should be considered legally binding on other states and whether the categorization as law has practical effects. Does it matter whether an international tax

\footnotetext{
role of Brazil could be regarded as important but not as a 'persistent objector rule' for the creation of the arm's length method as customary international law

${ }^{63}$ See Section 3.2.2 infra.

${ }^{64}$ OECD (2015), Designing Effective Controlled Foreign Company Rules, Action 3 - 2015 Final Report, OECD/G20 Base Erosion and Profit Shifting Project, OECD Publishing, Paris, available at doi.org/10.1787/9789264241152-en, at 9.

${ }^{65}$ Despite the fact that the United States changed to the formula apportionment, at the time that the arm's length standard was adopted 1930s, the United States also participated in this process. It was only in the 1980s that 'the United States realized that in many circumstances it is very difficult to find comparable transactions between unrelated parties on which to base the arm's length determination. It therefore, began the process of revising the regulations that govern transfer pricing. This culminate in 1995 with the adoption of two new methods, the comparable profit method and the profit split method, that rely much less on finding comparables (and in the case of the profit split method sometimes require no comparables at all)'. See Avi-Yonah, supra note 52, at 499.

${ }^{66} \mathrm{Ibid}$., at 500, including also the reference in footnote 112 to two cases: Barclays Bank PLC v. Franchise Tax Bd. Of cal., 512 U.S. 298 (Sup.Ct.1994) and Container Corp. of America v. Franchise Tax Bd., 463 U.S. 159 (Sup.Ct.1983).

${ }^{67}$ OECD (1998), Harmful Tax Competition: An Emerging Global Issue (1998), available at doi.org/10.1787/9789264162945-en.
} 
practice or norm is described as a "hard" law, a "customary" law, a "soft" law, or not law at all, if most countries feel compelled to abide by it in any case? ${ }^{68}$

Christians gives equal importance to both the objective element (state practice) and the subjective element (sense of legal obligation by the states). ${ }^{69}$ Analysing the OECD's harmful tax practices, Christians argues that:

in the case of consensus on harmful tax practices, state practice seems insufficiently widespread to describe the OECD's work as customary law. Fewer than half of the nations in the world have been involved in the initiative, and a growing number of states have abstained from it. Still, customary law is by nature dynamic: these tax norms could evolve into customary law if enough states sufficiently internalize them going forward. The OECD's current focus encourages internalization through monitoring any continuing and newly introduced preferential tax regimes [within or without the OECD membership] identified by member countries. $^{70}$

Regarding the subjective element, Christians argues that 'the OECD's guidance seems to lack the general legal obligation (opinio juris) associated with customary law, because the guidance is by its terms commendatory rather than obligatory. ${ }^{71}$ Therefore, in this case, the author concludes that the OECD Harmful Tax Practices cannot be regarded as international customary law. ${ }^{72}$ However, since BEPS Action 5, dealing with harmful tax practices, is also a BEPS Minimum Standard, this conclusion can change in light of the implementation of the BEPS Minimum Standards by the 137 jurisdictions participating in the BEPS Inclusive Framework.

\subsubsection{Recent international tax law developments and customary international law}

The two examples above show that, in international tax law, the discussion of customary international law has taken place mainly regarding the OECD/UN tax treaty Models, ${ }^{73}$ the OECD Harmful Tax Practices, and the OECD Transfer pricing guidelines containing the arm's length

\footnotetext{
${ }^{68}$ A. Christians, 'Hard Law \& Soft Law in International Taxation', (2007) 25(2) Wisconsin International Law Journal, available at ssrn.com/abstract $=988782$, at 3 .

${ }^{69}$ According to this author, 'customary international law is characterized by two fundamental elements: states uniformly comply with it (sometimes referred to as the objective element), and they do so out of a sense of legal obligation (sometimes referred to as the subjective element). The role of each of these requirements in determining whether something is a customary law is the subject of extensive analysis in the international law literature, but the key seems to be that for a custom to be a law, it must be recognized by states as legally binding. Within this framework, whether the OECD's harmful tax practices guidance can be described as customary law depends upon whether state practice is sufficiently widespread and whether countries go along because of "a general legal obligation necessitating it." Both components are needed: widespread practice alone might indicate that a social, political, or other kind of norm or practice exists, but the obligation component seems necessary to identify the norm or practice as law'. Ibid., at 6.

${ }^{70} \mathrm{Ibid}$., at 6 . In international law, the acceptance of state practice can be also tacit (for instance due to silence or lack of action by the state). According to both the ILA and the ILC, silence can be (under certain conditions) taken into account as a way to adopt state practice. The silence does not mean that the state is against the rule, unless they adopt practices that are clearly in opposition of the emergent rule. See M. Wood, Second Report on Identification of Customary International Law, UN Doc. A/CN.4/672, para. 57 , at 50 .

${ }^{71}$ See Christians, supra note 68 , at 6.

${ }^{72}$ For Christians, the OECD harmful tax practices guidance thus seems to fall short of international law in the formal, or 'hard' sense of treaty or custom. Yet states feel compelled to adhere to the recommendations and guidelines, perhaps not least because there are - at least potentially - real consequences for failure to comply. If the OECD initiative is not law, it nevertheless creates a strong degree of obligation among member and nonmember states alike. This sense of obligation makes it difficult to simply dismiss the guidance as 'not law'. Therefore, this author argues that in this case, the OECD harmful tax practices can be regarded as soft law. Ibid., at 7-8.

${ }^{73}$ See, for a recent analysis of the role of the UN/OECD as model treaties, C. West, 'References to the OECD Commentaries in Tax Treaties: A Steady March from "Soft" Law to "Hard" Law?', (2017) 9 World Tax J. 117.
} 
principle. ${ }^{74}$ More recently, in light of the developments in international taxation including the development on the global standard of transparency and exchange of information (since 2009) ${ }^{75}$ and BEPS developments (since 2013), tax scholars have addressed the need for revisiting international customary law. ${ }^{76}$

For instance, in 2013, Pistone ${ }^{77}$ argued that the standard of global fiscal transparency developed by the OECD and also followed by the $\mathrm{EU}^{78}$ shows that customary international law is created in this domain and therefore, for Pistone, it may be questioned as to whether or not a Member State may conclude an international agreement with a third country that runs counter to fiscal transparency'. ${ }^{79}$

Another tax scholar, García Antón, ${ }^{80}$ when addressing the shifting from bilateralism to multilateralism has also highlighted that in international taxation 'the presence of customary international law constitutes a huge step forward in achieving a multilateral treaty'. ${ }^{81}$ However, as rightly stated by García Antón about taxation, there is still high controversy in some of the most important tax concepts, for instance, regarding the definition of tax or the choice of methods for the elimination of the double taxation. ${ }^{82}$

In my view, this can be also be the case in respect of allocation of taxing rights between source country and residence country, since the different interests from developing countries (more source taxation) vs. developed countries (more residence taxation) can make it difficult to achieve rules that are accepted by all countries. Two examples illustrate this. The first is the OECD-G20 reluctance to deal with allocation of taxing rights in the BEPS Project. ${ }^{83}$ The second is the 2019 OECD consultation on the taxation of the digital economy ${ }^{84}$ that presents policy options ${ }^{85}$ which represent different countries' approach, (i) from the OECD-G20 countries, (ii) from the United States, and (iii) from the EU, and G24 (mainly developing) countries. Due to the lack of a consensus for one of the three policy options, the OECD Secretariat presented its own 'Unified Approach Proposal' which is being discussed at the time of writing. ${ }^{86}$

More recently (2019), Hongler, applying Trachtman's work, argues that customary international law is not an efficient source of law making for the international tax regime. For Hongler, 'various reasons have proven that the development of customary international tax law might be limited due to its complexity, technicality, and the fact that the legality principle

\footnotetext{
${ }^{74}$ More recently, in transfer pricing, the arm's length principle and its acceptance by countries has been addressed by tax scholars. See, for instance, A. Turina, 'Back to Grass Roots: The Arm's Length Standard, Comparability and Transparency Some Perspectives from the Emerging World', (2018) 10 World Tax J. 295, and the case law comparative study of 20 countries around the world, by E. A. Baistrocchi and I. Roxan (eds.), Resolving Transfer Pricing Disputes: A Global Analysis (2012).

${ }^{75}$ See Section 3.2.2 infra.

${ }^{76}$ See, for instance, D. Weber, EU law and the Building of Global Supranational Tax Law: EU BEPS and State Aid (2017).

${ }^{77}$ P. Pistone, 'Exchange of Information and Rubik Agreements: The Perspective of an EU Academic', (2013) 67 Bull. Intl. Taxn. 219.

${ }^{78}$ For instance, by introducing the Standard of Good Governance in Tax matters that consists, since 2008, of the standards of transparency, exchange of information, and fair tax competition and since 2018 the BEPS 4 Minimum Standards.

${ }^{79}$ See Pistone, supra note 77, at 223.

${ }^{80}$ R. García Antón, 'The 21st Century Multilateralism in International Taxation: The Emperor's New Clothes?', (2016) 8 World Tax J. 148.

${ }^{81}$ Ibid., at 187.

${ }^{82}$ Ibid., at 187 .

${ }^{83}$ See I. J. J. Burgers and I. J. Mosquera Valderrama, 'Corporate Taxation and BEPS: A Fair Slice for Developing Countries?', (2017) 8 Erasmus Law Review 29, available at doi.org/10.5553/ELR.000077.

${ }^{84}$ OECD (2019), 'Addressing the Tax Challenges of the Digitalisation of the Economy: Public Consultation Document', available at www.oecd.org/tax/beps/public-consultation-document-addressing-the-tax-challenges-of-the-digitalisation-ofthe-economy.pdf.

${ }^{85}$ The three policy choices are respectively (i) user participation, (ii) marketing intangibles, or (iii) defining a 'significant economic presence'.

${ }^{86}$ OECD (2019), 'Secretariat Proposal for a “Unified Approach” under Pillar One', available at www.oecd.org/tax/beps/ public-consultation-document-secretariat-proposal-unified-approach-pillar-one.pdf.
} 
is often crucial for tax purposes' ${ }^{87}$ Some of the rules examined by Hongler are, for instance, the prohibition of juridical double taxation, the arm's length principle, and the non-taxation of diplomatic and consular personnel in the residence state. For Hongler, these rules either do not meet the requirement of state practice or the requirement of acceptance by law (opinio juris) or both. ${ }^{88}$

In this regard, we agree with Hongler that in some cases, it could be difficult to develop customary international law since both requirements will need to be met, and this is not the case for instance:

- in international tax law rules that by their own nature can be voluntarily adopted or not (e.g., use of arm's length principle and introduction of CFC rules);

- in international tax law rules that can result in a different outcome resulting from the negotiation between countries (e.g., permanent establishment's threshold);

- in international tax law rules that are introduced following the use of coercive measures (e.g., exchange of information and repeal of bank secrecy);

- in international tax law rules that deal with the allocation of taxing rights (e.g., withholding tax for dividend, interest, and royalties).

However, the use of a general anti-abuse clause (i.e., principal purpose test) in tax treaties has been widely accepted by jurisdictions participating in the BEPS Inclusive Framework and also by jurisdictions' signatories of the BEPS multilateral instrument. The question, therefore, should be whether the widespread practice of including a principal purpose test in tax treaties is enough to create a customary international tax law rule.

Unlike the definition of tax or allocation of taxing rights, the principal purpose test is regarded by developed and developing countries as one of the most important and desirable solutions to tackle treaty abuse by multinationals. Furthermore, even though the principal purpose test can be found in bilateral tax treaties concluded by countries, tax scholars have correctly argued that this test is, by its own nature, often general, vague, and imprecise ${ }^{89}$ and, therefore, it follows some of the main features highlighted by international law scholars when addressing international customary law. ${ }^{90}$

The following section will address some of the arguments that can be used to consider the BEPS Minimum Standard of the principal purpose test as a rule of customary international law.

\section{Is the principal purpose test customary international law?}

\subsection{Principal purpose test}

\subsubsection{The principal purpose test in the BEPS Inclusive Framework and MLI}

3.1.1.1 BEPS Action 6 and $M L I$. The principal purpose test is one of the four minimum standards (BEPS Action 6) ${ }^{91}$ adopted by countries in the BEPS Inclusive Framework and/or the MLI. ${ }^{92}$ The principle purpose test emerged during the 2013-2015 work carried out by the OECD BEPS 44 group and thereafter (2016) by acceptance as a minimum standard by countries committed to the BEPS Inclusive Framework meeting in Tokyo, Japan. Signature of the MLI took place after

\footnotetext{
${ }^{87}$ See Hongler, supra note 16 , at 165.

${ }^{88}$ Arm's length both, diplomatic acceptance by law and double non taxation state practice.

${ }^{89} \mathrm{Cf}$. Section 3.1.2 infra.

${ }^{90}$ Trachtman argues, referring to Villiger, that 'We should bear in mind that customary law is, by nature, often general, vague, and imprecise.' See Trachtman, supra note 18, at 181. See also M. E. Villiger, Customary International Law and Treaties: A Manual on the Theory and Practice of the Interrelation of Sources (1997), at 103.

${ }^{91}$ See OECD (2019), Prevention of Treaty Abuse, supra note 12.

${ }^{92}$ Art. 7 Multilateral Convention to Implement Tax Treaty Related Measures to Prevent Base Erosion and Profit Shifting (MLI), available at www.oecd.org/tax/treaties/multilateral-convention-to-implement-tax-treaty-related-measures-to-preventBEPS.pdf.
} 
these two developments, i.e., in 2017. In general, most of the countries that are in the BEPS MLI have also committed to the BEPS Inclusive Framework. One exception is Cyprus, which has only signed the MLI.

Countries can choose one of the following three forms: (i) principal purpose test; (ii) principal purpose test with either a simplified or detailed limitation on benefits provisions; and (iii) a detailed LOB with anti-abuse measures to counteract conduit financing. For instance, countries participating in the BEPS Inclusive Framework committed to the implementation of the principal purpose test with or without a limitation on benefits, except the United States which decided to choose option (iii). ${ }^{93}$

\subsubsection{Menu of options in the MLI. Unlike the BEPS Inclusive Framework that provides the} minimum standard to be applicable by countries participating in the framework, the MLI provides more flexibility in the choices by countries. Countries can make choices in the MLI that are illustrated as follows:

First, the MLI applies only to the treaties that the country refers to in the MLI as being covered tax agreements. The treaties that are not covered by MLI are negotiated bilaterally. Second, for each specific article of the MLI, countries may decide to opt-in or to opt-out of the provisions of the article. For instance, in respect of the principal purpose test, countries have decided specifically to opt-in for a principal purpose test and in some cases, the countries (e.g., the Netherlands, Curaçao, Malta, Cyprus, and Singapore) have also chosen discretionary relief (Article 7(4) of MLI). In addition, some countries (e.g., Colombia) have chosen to apply the principal purpose test as an interim measure and, then, to bilaterally negotiate tax treaties to determine whether to include the principal purpose test with or without the LOB. Other countries (e.g., Senegal) provide for a reservation to apply the principal purpose test if there is a main purpose test in the tax treaty. ${ }^{94}$

The result is a complex menu of options for the countries participating in the MLI, and the mismatches that can result in multiple mini-treaty negotiations. For instance, if a country has chosen the principal purpose test and the other country has chosen the principal purpose test with simplified LOB, these two countries will need to decide whether the simplified LOB can be introduced, but this will require a mini-treaty negotiation.

Since the principal purpose test is the minimum standard if countries have not agreed on another rule, then the minimum standard can still be applicable as a residual rule (i.e., a rule that applies, unless the parties have not agreed on something different). ${ }^{95}$ This is, for instance, the case of Belize which has decided not to include any option and, therefore, the principal purpose test as the minimum standard will apply by default.

3.1.1.3 MLI and customary international law. In light of these developments, it can be safely argued that the signature (and ratification) of the MLI by countries can affect the treaty practice of the principal purpose test, mainly due to the flexibility in the choices by countries in the MLI. The choices in the MLI and the subsequent treaty practice may contribute to enhancing the formation of the principal purpose test as a rule of customary law. ${ }^{96}$

\footnotetext{
${ }^{93}$ International Revenue Code Title 26. See IRC $\$ 1.881-3$, Conduit financing arrangements, available at www.govinfo.gov/ app/details/CFR-1998-title26-vol9/CFR-1998-title26-vol9-sec1-881-3. For limitation on benefits (LOB) see peer review report March 2019, Section 3.2.2 infra.

${ }^{94}$ See the positions of countries in respect of the MLI at www.oecd.org/tax/treaties/beps-mli-signatories-and-parties.pdf.

${ }^{95}$ The residual rule has been also applied in respect of the application of the Vienna Convention on the Law of the Treaties. According to Gourgourinis: 'So to the extent to which the majority of the VCLT provisions reflect custom, one can conclude that the norms of the law of treaties apply residually, that is, "automatically, and without incorporation", 67 insofar as that they have not been explicitly derogated from by specific treaty provisions.' A. Gourgourinis, 'General/Particular International Law and Primary/Secondary Rules: Unitary Terminology of a Fragmented System’, (2011) 22(4) EJIL 993, at 1006.

${ }^{96}$ In international law, some authors have addressed the relationship between multilateral treaties and customary international law. See W. A. Thirlway, International Customary Law and Codification (1972). See also R. B. Bilder et. al., 'Disentangling Treaty and Customary International Law', Proceedings of the Annual Meeting, (1987) 81 American Society of International Law 157.
} 
More specifically in the relationship of the MLI and customary international law, García Antón has rightly argued that the 'MLI presents on one side the multilateral layer representing a high degree of consensus in the long march towards customary international law, and on the other side, the bilateral layer introducing a high degree of flexibility'. Therefore, he argues that 'rather than coordination, multilateralism advocates for globally enforcing normative principles with a clear aspiration to become Customary International Law, ${ }^{97}$ The elements of international customary law for the principle purpose test will be further addressed in Section 3.2 below.

\subsubsection{Main requirements of the principal purpose test}

The 2015 OECD final report addressing BEPS Action 6 introduced an article called Entitlement to Treaty Benefits. This article contains the principal purpose test and it states:

Notwithstanding the other provisions of this Convention, a benefit under this Convention shall not be granted in respect of an item of income or capital if it is reasonable to conclude, having regard to all relevant facts and circumstances, that obtaining that benefit was one of the principal purposes of any arrangement or transaction that resulted directly or indirectly in that benefit, unless it is established that granting that benefit in these circumstances would be in accordance with the object and purpose of the relevant provisions of this Convention. ${ }^{98}$

In general, the principal purpose test has two tests (requirements), i.e., a subjective test and an objective test. The subjective element needs to be demonstrated by the tax administration and states if it is reasonable to conclude, having regard to all relevant facts and circumstances that obtaining the benefit was one of the principal purposes of any arrangement or transaction that resulted directly or indirectly in that benefit'. The objective element needs to be demonstrated by the taxpayer, and states if it is established that granting that benefit in these circumstances would be in accordance to the object and purpose of the relevant provisions of the Covered Tax Agreement'.

Following the elements described in Section 2.1, for a rule of customary international law to exist, the following paragraphs will address the principal purpose test in light of the objective element of state practice and of the subjective element, mainly to refer to the acceptance and sense of compliance by countries with the principal purpose test.

\subsection{Principal purpose test and customary international law}

\subsubsection{Objective element: State practice: Uniform, extensive, representative, and consistent}

3.2.1.1 Guiding principle and Minimum Standard. The content of the principal purpose test is, to some extent, based on the guiding principle ${ }^{99}$ available in the 2003 OECD Commentary. ${ }^{100}$ The guiding principle states that:

\footnotetext{
${ }^{97}$ For García Antón, 'The examples in the field of Public International Law, namely in the Law of the Sea, show the precise interaction between a multilateral treaty and customary international law, either by codifying it or by introducing norms in symbolical aspiration to become it. Such strong consensus encapsulated in a multilateral treaty must be protected against national interferences. Therefore, a shield emerges to prevent reservations to the core areas, to articulate mandatory dispute resolution mechanisms and finally to restore the original consensus in case that an amendment to the treaty is needed.' R. García Antón. 'Multilateral Dynamics in Bilateral Settings: Back to Realpolitik', (2019) 4 British Tax Review 462.

${ }^{98}$ Article X. OECD (2015), Preventing the Granting of Treaty Benefits in Inappropriate Circumstances, Action 6 - 2015 Final Report, OECD/G20 Base Erosion and Profit Shifting Project, OECD Publishing, Paris, available at doi.org/10.1787/ 9789264241695-en, at 55.

${ }^{99}$ D. G. Duff, 'Tax Treaty Abuse and the Principal Purpose Test - Part II', (2018) 66 Can Tax J 947.

${ }^{100}$ The OECD has developed a Model for Tax Treaties including an OECD Commentary. This Model and Commentary are guidelines/recommendations used by countries to conclude or interpret a bilateral tax treaty.
} 
the benefits of a double taxation convention should not be available where a main purpose for entering into certain transactions or arrangements was to secure a more favourable tax position and obtaining a more favourable treatment in these circumstances would be contrary to the object and purpose of the relevant provision. ${ }^{101}$

However, unlike the guiding principle that was only mentioned in the OECD Commentary and was not widely used by countries, ${ }^{102}$ the principal purpose test has been introduced in BEPS Action 6 as a minimum standard, in Article 7 of the MLI, and in Article 29 of the 2017 OECD Model and its corresponding OECD Commentary. The process of adoption of the principal purpose test demonstrates that it is a state practice that is applied uniformly, extensively, representatively, and consistently by countries.

From the 137 countries committed to the BEPS Inclusive Framework, 136 have committed to include the principal purpose test as the minimum standard either in bilateral negotiations or by opting in for this standard in the MLI. ${ }^{103}$ In addition, Cyprus has committed to include the principal purpose test as the MLI's signatory.

The adoption of the BEPS Action 6, the introduction of the BEPS Inclusive Framework, and the signature of the MLI instrument have taken place in a short period of time (since 2013). Despite this short timeframe, more than half of the countries around the world have committed to the principal purpose test. Therefore, it can be safely argued that the requirement of durability for a practice to emerge as customary international law is not an obstacle for the state practice to exist.

3.2.1.2 Peer review of the minimum standard. In the 2018 peer review report of Action 6 in 116 jurisdictions, 56 countries expressed their choice for the principal purpose test; ${ }^{104} 27$ countries decided to apply the principal purpose test with a simplified or detailed LOB. ${ }^{105}$ Thirty-two

\footnotetext{
${ }^{101}$ Para. 9.5 of the Commentary on Art. 1 of the 2003 OECD Model Convention. See Model Tax Convention on Income and on Capital: Condensed Version 2003, available at doi.org/10.1787/mtc_cond-2003-en.

${ }^{102}$ The guiding principle was in the Commentary to Art. 1 OECD 2003 Tax Treaty Model, but it was not included in the Model itself. Therefore, the application of the principle was mainly for purposes of interpretation of a tax treaty, but it was a provision in the treaty. The principle purpose test has found its way into Art. 292017 Tax Treaty Model with its respective commentary, Model Tax Convention on Income and on Capital: Condensed Version 2017, available at doi.org/10.1787/ mtc_cond-2017-en. As van Weeghel rightly states: 'One may wonder why, at the time (in 2003), the changes that have now found their way into the 2017 OECD Model - in particular, the preamble and the PPT - were not included in the 2003 OECD Model. Perhaps there was no consensus or there was a fear that incorporating these into the OECD Model would erode the position that domestic anti-avoidance principles, including substance over form, could be applied in respect of existing tax treaties in the absence of explicit clauses in those treaties. It is clear that in various places in the Commentary on Article 1 of the 2003 OECD Model, the drafters reiterate that, regardless of whether a country takes a factual approach or an interpretive approach to tax treaty interpretation, tax treaty benefits can be denied in cases of abuse.' S. van Weeghel, 'A Deconstruction of the Principal Purpose Test', (2019) 11 World Tax J. 3.

${ }^{103}$ See, for instance, peer review Action 6 addressing the choices of 116 jurisdictions that, as of 30 June 2018, were committed to the BEPS Inclusive Framework. In general, countries committed to PPT and sometimes with a simplified or detailed LOB.

${ }^{104}$ From the peer review of 116 countries, 56 have explicitly mentioned the application of PPT: Andorra, Australia, Austria, Barbados, Burkina Faso, Cameroon, Costa Rica, Cote d'Ivoire, Croatia, Curacao, Czech Republic, Egypt, Estonia, Finland, France, Gabon, Georgia, Guernsey, Hong Kong, Hungary, Ireland, Isle of Man, Israel, Italy, Jersey, Korea, Liechtenstein, Lithuania, Luxembourg, Malaysia, Malta, Monaco, the Netherlands, New Zeeland, Nigeria, Pakistan, Panama, Portugal, Qatar, Romania, San Marino, Saudi Arabia, Serbia, Singapore, Slovenia, South Africa, Spain, Sweden, Switzerland, Tunisia, Turkey, Ukraine, United Arab Emirates, the United Kingdom, Uruguay, and Zambia. See OECD (2019), Prevention of Treaty Abuse, supra note 12

${ }^{105}$ From the peer review of 116 countries, 27 have explicitly mentioned the application of PPT combined with simplified or detailed LOB: Argentina, Belgium, Brazil, Bulgaria, Canada, Chile, China, Colombia, Denmark, Germany, Greece, Iceland, India, Indonesia, Jamaica, Japan, Kazakhstan, Latvia, Mauritius, Mexico, Norway, Peru, Poland, Russia, Senegal, the Seychelles, and the Slovak Republic. See OECD (2019), Prevention of Treaty Abuse, supra note 12.
} 
countries did not mention their choice but, since the minimum standard is the principal purpose test, it is expected that these countries will apply it (i.e., residual rule). ${ }^{106}$

Only one country (the United States) deviated from the principal purpose test during the drafting of BEPS Action 6 (which can be regarded as the process of the emergence of the principal purpose test). The United States decided to apply its own rules, i.e., detailed limitation on benefits (LOB) and anti-conduit financing rules. Even though countries that are signatories of the MLI included their tax treaty with the United States as a covered agreement in the MLI and also with the choice for a principal purpose test, the United States decided not to sign the MLI. Therefore, it is expected that the negotiation of tax treaties with the United States will take place bilaterally. ${ }^{107}$

In practice, since the United States is the only country that has chosen a different path than the application of the principal purpose test, then, the question is whether the United States can be regarded as a persistent objector and, if so, is the result a fragmented customary international law? This can have consequences for the interpretation of the principal purpose test as a rule of customary international law. The role as a persistent objector was not followed by other countries since they decided to follow either the principal purpose test or the principal purpose test with limited or simplified LOB.

For the countries negotiating bilateral tax treaties with the United States, it is important to keep in mind that, if the principal purpose test is a rule of customary international law, then these countries can be regarded as being in violation of customary international law. However, if the principal purpose test is a residual customary rule, then countries are, in principle, free to agree on something different and, if not, then the principal purpose test will apply. Further research should be carried out regarding the role of the United States as a persistent objector and the use of the principal purpose test as a residual customary rule.

The description above shows that the principal purpose test is the common denominator in all cases (except the United States) and that countries are required to implement the principal purpose test as the minimum standard. Nevertheless, it needs to be kept in mind that countries can choose (i) whether the principal purpose test is adopted in the MLI, or (ii) by means of a bilateral treaty negotiation, and (iii) whether there is discretionary relief (Article 7(4) MLI) that allows the tax administration to still grant the tax treaty benefit prior to consultation with the relevant tax administration. These differences can result in differences in implementation or interpretation, but not in the state practice as such, since the principal purpose test rule has been accepted by the majority of the jurisdictions that have committed to implementing this rule.

One final element that should be analysed in state practice is the affected states doctrine. Even though this doctrine has not been created by Global North countries, these countries have relied on this doctrine to invoke 'specially-affected status in a manner that gives powerful states almost complete control over custom formation'. ${ }^{108}$ In this regard, taking into account the role of BEPS 44

\footnotetext{
${ }^{106}$ Angola, Anguilla, Bahamas, Bahrain, Belize, Benin, Bermuda, Botswana, British Virgin Islands, Brunei, Cayman Islands, Congo, Djibouti, Haiti, Kenya, Liberia, Macau, Maldives, Mongolia, Montserrat, Oman, Papua New Guinea, Paraguay, Saint Kitts \& Nevis, Sierra Leone, Sri Lanka, Saint Lucia, Thailand, Trinidad \& Tobago, Turks \& Caicos Island, and Vietnam. See OECD (2019), Prevention of Treaty Abuse, supra note 12.

${ }^{107}$ As stated in the peer review report of Action 6 (March 2019), 'the United States expects to comply with the minimum standard through a detailed LOB which is not available through the MLI. Therefore, the United States did not sign the MLI and will implement the minimum standard bilaterally. The United States' agreements with the following 45 jurisdictions contain an LOB and are supplemented by domestic anti-conduit rules: Australia, Austria, Bangladesh, Barbados, Belgium, Bulgaria, Canada, China (People's Republic of), Cyprus, Czech Republic, Denmark, Estonia, Finland, France, Germany, Iceland, India, Indonesia, Ireland, Israel, Italy, Jamaica, Japan, Kazakhstan, Latvia, Lithuania, Luxembourg, Malta, Mexico, the Netherlands, New Zealand, Portugal, Russia, Slovak Republic, Slovenia, South Africa, Spain, Sri Lanka, Sweden, Switzerland, Thailand, Tunisia, Turkey, Ukraine, Venezuela. Signed protocols with Hungary and Poland contain an LOB and are supplemented by domestic anti-conduit rules. The agreements with Egypt, Korea, Morocco ${ }^{*}$, Norway, and Trinidad and Tobago have a limited anti-treaty shopping rule and are supplemented by domestic anti-conduit rules. The agreement with the United Kingdom contains an LOB and anti-conduit rules and is supplemented by domestic anti-conduit rules'. See OECD (2019), Prevention of Treaty Abuse, supra note 12, at 249.

${ }^{108}$ K. J. Heller. 'Specially Affected States and the Formation of Custom', (2018) 112 AJIL 191, at 241.
} 
(developed: OECD and G20 countries) in the development of the BEPS Project, the question remains how developing (or Global South) countries will benefit from these developments. If the principal purpose test is a rule of customary international law, what would be the role of developing countries in the development of the rules of customary international law?

For Keller, understanding this doctrine can help countries in the Global South to claim the status as 'specially affected states' by customary international law. ${ }^{109}$ Therefore, further research should be carried out by the International Law Association and/or the UN ILC in the role of the affected states doctrines to ensure that countries in the Global South can also claim their role as states affected by the customary international tax law rule (i.e., the principal purpose test). This approach may also open a door to a more important role of the United Nations and its ILC in the development of BEPS for developing countries. The role of the United Nations is, at the time of writing, limited to co-operation in the platform for Collaboration on Tax. ${ }^{110}$

To sum up, at the time of writing 137 jurisdictions (136 of the Inclusive Framework and Cyprus of the MLI) are adopting the principal purpose test. The choice for this test by all countries except the United States shows that it will be widely used by countries (developed and developing) around the world to tackle treaty abuse either in bilateral tax treaty negotiations, or in the MLI that modifies bilateral tax treaties. Therefore, this principal purpose test is representative, extensive, uniform, and consistent.

\subsubsection{Subjective element: Accepted as law (opinio juris)}

In the past, the OECD ${ }^{111}$ and the UN acted by means of UN treaty models, guidelines, and recommendations. Countries decided to use these guidelines in their tax treaties or introduce the rules in their domestic law. For instance, the arm's length principle and the methods to determine the transfer pricing of the OECD Transfer Pricing Guidelines are followed by almost all countries around the world. ${ }^{112}$ As mentioned above by Christians (Section 2.3.2), these models are not regarded as hard law, nor as a customary law, but as soft law. Countries may or may not decide to follow these models.

However, the 2008 financial crisis created a new framework in which the OECD, following the political mandate of the G20, decided to introduce global standards to be followed not only by the OECD or G20 countries but also by developing countries. As in the BEPS Project, these standards have been developed by the OECD with the political support of the G20. Other countries (non-OECD, non-G-20) have been invited to participate on equal footing as members of the Global Transparency Forum. As of March 2020, 161 countries are members of this forum and are participating on the implementation, monitoring, and peer review of these standards. ${ }^{113}$

\footnotetext{
${ }^{109}$ Ibid., at 242.

${ }^{110}$ The Platform for Collaboration on Tax is a joint effort launched in April 2016 by the International Monetary Fund (IMF), the Organization for Economic Co-operation and Development (OECD), the United Nations (UN), and the World Bank Group (WBG). The Platform is designed to intensify the co-operation between these international organizations (IOs) on tax issues. See www.oecd.org/ctp/platform-for-collaboration-on-tax.htm. See also W. Lips and I. J. Mosquera Valderrama, 'Global Sustainable Tax Governance in the OECD-G20 Transparency and BEPS initiatives', in C. Brokelind and S. van Thiel (eds.), Tax Sustainability in an EU and International Context (2020).

${ }^{111}$ The OECD aims were stated in the 1960 Convention on the Organisation for Economic Co-operation and Development of 14 December 1960. To achieve these aims, the OECD may develop standards, recommendations, and models to be used by OECD countries. Article 5 of the 1960 Convention states that in order to achieve these aims the OECD 'may (a) take decisions which, except as otherwise provided, shall be binding on all the Members; (b) make recommendations to Members; and (c) enter into agreements with Members, nonmember States and international organisations'. See www.oecd.org/general/ conventionontheorganisationforeconomicco-operationanddevelopment.htm.

${ }^{112} \mathrm{~W}$ ith some exceptions - the United States, Brazil, and to some extent Argentina - regarding the introduction of the sixth method.

${ }^{113}$ See www.oecd.org/tax/transparency/.
} 
The first example was the global standard of exchange of information on request introduced in 2009 that was followed later (2013) by the global standard of automatic exchange of financial reporting information. Countries committed to the Global Transparency Forum and also signed instruments to facilitate the exchange of information. ${ }^{114}$ In order to assess the compliance of countries with these standards, a peer review system was introduced. Due to this peer review system, and in order to facilitate the effective exchange of information, countries such as the Netherlands, Switzerland, Uruguay, and Luxembourg, among others, changed their legislation - also including the repeal of the notification procedure to the taxpayer in respect of the first country and the repeal of bank secrecy for the latter three countries.

Following the same process, the implementation of the BEPS Minimum Standards by countries belonging to the Inclusive Framework is being reviewed by countries (peer review). As a result of the peer review, countries are recommended to change their rules to facilitate the implementation of the BEPS 4 Minimum Standards.

In respect of Action 6, the first peer review report was published in March 2019 for 116 countries/jurisdictions. ${ }^{115}$ It focuses on whether the preamble and the principal purpose test are in place in the tax treaties of the peer reviewed countries. After this first assessment, it is expected that countries will start reviewing their tax treaties so that they are regarded as being compliant with the minimum standard of Action 6.

The starting point of the peer review of Action 6 is that countries are free to implement the minimum standard either through the MLI or bilaterally. However, one important element in the implementation mentioned by the OECD peer review report is that 'a jurisdiction is required to implement the minimum standard when requested to do so by another member of the Inclusive Framework, ${ }^{116}$ even in the absence of the MLI. This requirement to implement the minimum standard of principal purpose results in countries having a sense of compliance with the minimum standard since, otherwise, the country can be regarded as being non-compliant with the standard.

In 2019, 116 jurisdictions were reviewed covering approximately 1,960 bilateral agreements and five multilateral agreements. ${ }^{117}$ Most of the peer reviewed jurisdictions have introduced or expressed their intention to introduce the principal purpose test with a preamble in their treaties, and in some cases supplemented with a simplified or a detailed LOB.

Even though, the choices made by countries in the MLI can result in differences in tax treaties (whether amended by the MLI or bilaterally) and perhaps differences in interpretation of the principal purpose test in light of the underlying treaty, ${ }^{118}$ the essence of the principal purpose test as an

\footnotetext{
${ }^{114}$ Examples of these instruments are the Multilateral Convention on Administrative Assistance in Tax Matters, the Common Reporting Standard, and the Multilateral Competent Authority Agreement for the exchange of financial accounting information.

${ }^{115}$ According to the peer review report: The first Peer Review covers 116 jurisdictions, which all prepared lists of their existing comprehensive income tax agreements in force on 30 June 2018. The lists indicated whether, at that time, each agreement included the provisions of the minimum standard, i.e., a complying preamble and the necessary anti-abuse provision(s). See OECD (2019), Prevention of Treaty Abuse, supra note 12.

${ }^{116}$ See OECD (2019), Prevention of Treaty Abuse, supra note 12, para. 15, at 16.

${ }^{117}$ These five agreements have been reported by some of the jurisdictions participating in the BEPS Inclusive Framework: (i) the Arab Maghreb Union Income Agreement, reported by Tunisia; (ii) the agreement among the members of the CARICOM, reported by Barbados, Belize, Jamaica, Saint Kitts \& Nevis, Saint Lucia, and Trinidad \& Tobago, which was listed under the MLI by Barbados and Jamaica; (iii) the Regulation 08/2008/COM adopting the rules for the avoidance of double taxation within the West African Economic and Monetary Union and the rule for assistance in tax matters, reported by Benin, Burkina Faso, Côte d'Ivoire, and Senegal; (iv) the Decision 578 of the Andean Community Commission which establishes a regime for the avoidance of double taxation and the prevention of fiscal evasion, reported by Colombia and Peru; and (v) the Nordic Convention, reported by Denmark, Finland, Iceland, Norway, and Sweden. See OECD (2019), Prevention of Treaty Abuse, supra note 12, para. 34, at 26.

${ }^{118}$ On the analysis of the principal purpose test see C. Elliffe, 'The Meaning of the Principal Purpose Test: One Rig to Bind Them All?,' (2019) 11 World Tax J. 47; P. Piantavigna, 'The Role of the Subjective Element in Tax Abuse and Aggressive Tax Planning', (2018) 10 World Tax J. 193; D. Weber, 'The Reasonableness Test of the Principal Purpose Test Rule in OECD BEPS
} 
emerging rule of customary international law will be the same. These differences in interpretation will be interesting for further research on the principal purpose test as a rule of customary international tax law (see Section 3.3 below). ${ }^{119}$

As in the standard of exchange of information, it can reasonably be expected that countries will comply with the principal purpose test and, therefore, tax treaties will be amended (either through the MLI or bilaterally). Because of the changes that countries will introduce to comply with the principal purpose test, it can be safely argued that the subjective element acceptance by law (opinio juris) exists in respect of the principal purpose test as a rule of customary international law.

Another element to analyse the subjective element is the acceptance by law and the role of countries in the development of the principal purpose test as a rule of customary international law. In the past, Akehurst has referred to custom as a source of international law, and the documents that can provide evidence of acceptance by law (opinio juris). Examples are, for instance, statements in the travaux préparatoires and statements in the treaty. ${ }^{120}$

In respect of BEPS Action 6, the principal purpose test has been referred to in the BEPS Project, BEPS Action 6, the MLI, explanatory statement, Article 292017 OECD Model and its Commentary, and the 2018 Peer Review Report. In all of these documents, countries have not objected to or challenged the statements of the OECD and BEPS 44 group that the principal purpose test is the standard to be implemented.

For instance, the BEPS Action 6 Final report stated:

Countries have therefore agreed to include anti-abuse provisions in their tax treaties, including a minimum standard to counter treaty shopping. They also agree that some flexibility in the implementation of the minimum standard is required as these provisions need to be adapted to each country's specificities and to the circumstances of the negotiation of bilateral conventions. ${ }^{121}$

This statement that, in principle, was drafted by the OECD and the countries belonging to the BEPS 44 group, went unchallenged by countries participating in the BEPS Inclusive Framework. The report stated that a certain degree of flexibility will be granted to the jurisdictions, but that the report recommends a 'minimum level of protection that should be implemented'. ${ }^{122}$ This minimum level of protection has been introduced in the principal purpose test either in the BEPS Inclusive Framework and/or the MLI. This acceptance is also strengthened in the 2018 peer review, where 116 jurisdictions expressed their commitment to the minimum standard and mainly to the principal purpose test (except the United States).

Another example that shows the acceptance as law is the adoption by states of the form of the minimum standard which includes the preamble, and either (i) the principal purpose test, (ii) the principal purpose test and simplified or detailed LOB, or (iii) detailed LOB and anti-conduit financing arrangements. ${ }^{123}$ The state practice described in Section 3.2.1 shows that countries have

Action 6 (Tax Treaty Abuse) versus the EU Principle of Legal Certainty and the EU Abuse of Law Case Law', (2017) 1 Erasmus Law Review 48.

${ }^{119}$ The interpretation of customary international law is being addressed by the ERC Project TRICI-LAW. See www.rug.nl/ research/groningen-centre-for-law-and-governance/eu-projects/trici-law/.

${ }^{120}$ M. Akehurst, 'Custom as a Source of International Law', (1975) 47(1) British Yearbook of International Law, at 45.

${ }^{121}$ See OECD (2015), Preventing the Granting of Treaty Benefits in Inappropriate Circumstances, supra note 98 , at 9.

${ }^{122}$ Ibid., at 14 .

${ }^{123}$ Given the risk to revenues posed by treaty shopping, countries have committed to ensure a minimum level of protection against treaty shopping (the 'minimum standard'). That commitment will require countries to include in their tax treaties an express statement that their common intention is to eliminate double taxation without creating opportunities for non-taxation or reduced taxation through tax evasion or avoidance, including through treaty shopping arrangements. Countries will implement this common intention by including in their treaties: (i) the combined approach of an LOB and PPT rule described above, (ii) the PPT rule alone, or (iii) the LOB rule supplemented by a mechanism that would deal with conduit financing arrangements not already dealt with in tax treaties. Ibid., at 10. 
chosen for the principal purpose test also including a simplified or detailed LOB and that the only country that has chosen option (iii) is the United States.

\subsection{Principal purpose test as a rule of customary international tax law}

The principal purpose test as a rule of customary law can have several consequences. The first is that the principal purpose test as a rule of customary law can bind countries if these countries have not committed to the BEPS Inclusive Framework or have not signed the multilateral treaty (MLI). This is true for the remaining jurisdictions outside the 137 jurisdictions that have agreed on the principal purpose test.

The principal purpose test aims to prevent aggressive tax planning by multinationals and/or individuals. Therefore, its widespread use may facilitate tax administrations in applying this test to challenge aggressive tax planning structures without having to use a tax treaty. The negotiation of a bilateral tax treaty takes time and, in some cases, the adoption of the MLI is regarded as burdensome for developing countries (due to its complexity). Hence, the introduction of the principal purpose test as a rule of customary international law can provide countries with a tool to tackle aggressive tax planning. Tackling aggressive tax planning can contribute to creating a 'fair tax system' for which companies and individuals pay their 'fair share' and countries collect more revenue for public services. This is a current societal challenge that has received the support of G20, OECD countries, and non-OECD countries including developing countries that can be addressed by giving the status of customary international law to the principal purpose test.

The second consequence addresses the United States, a country that has chosen a different rule (i.e., limitation on benefits (LOB) and anti-conduit financing arrangements). If the principal purpose test (PPT) is regarded as a rule of customary international law (CIL), it could be possible to argue that the United States is also bound by this rule. In this regard, Avi-Yonah rightly states that:

it will certainly be possible to argue in a few years that the PPT is CIL, since most of the world accepts it, and it certainly has good US roots in the business purpose/economic substance line of cases (see, e.g., Aiken Industries). Thus, it may be possible for the IRS one day to argue that a transaction that passes technical muster under the LOB of a treaty should nevertheless be rejected under the PPT even though the treaty does not contain the PPT language. Of course, the taxpayer will argue that the LOB overrides CIL and that the US has rejected the PPT. ${ }^{124}$

However, if the United States is regarded as a persistent objector to the principal purpose test, the United States may not be bound by it as a rule of customary tax law (see Section 3.2.1).

The third consequence is the interpretation of the principal purpose test as a rule of customary international law by courts and by arbitral tribunals. For instance, in the Vodafone case (a tax and investment case), ${ }^{125}$ the High Court of Delhi stated that an investment treaty shall be interpreted

\footnotetext{
${ }^{124}$ See Avi-Yonah, supra note 61, at 12. See, for a discussion of Aiken Industries Inc. v. Commissioner case 56 TC 925 (1971), Y. Brauner, 'Beneficial Ownership in and Outside US Tax Treaties', in M. Lang et al. (eds.), Beneficial Ownership: Recent Trends (2013), 143, at 146-9. See also D. Duff, 'Tax Treaty Abuse and the Principal Purpose Test - Part I', (2018) 66 Can. Tax J. 619, at 629.

${ }^{125}$ The Vodafone case deals with the indirect transfer of shares by Vodafone that took place outside of India and therefore, not subject to taxation in India in accordance to the tax treaty. However, the government of India decided unilaterally to tax this indirect transfer of shares. This case has received attention by tax scholars: see, for instance, S. Vasudevan and M. Nagappan, 'Indirect Transfer Taxation in India: From Vodafone to Cairn', (2017) 45 Intertax 665; K. Susarla and R. Ravisankar, 'Beyond Vodafone: The Ripple Effect', (2016) 22(1) Asia-Pacific Tax Bulletin 4; G. Loomer, 'The Vodafone Essar Dispute: Inadequate Tax Principles Create Difficult Choices for India', (2009) 21 National Law School of India Review 89.
} 
in accordance with the Vienna Convention on the Law of Treaties and customary international law. ${ }^{126}$ Following the rules of interpretation, the interpretation of the principal purpose test as a rule of customary law will have to be made in good faith. Therefore, countries would have to apply these rules even if they are not signatories of the Vienna Convention on the Law of the Treaties (e.g., the United States). ${ }^{127}$

\section{Final remarks}

Unlike the previous discussions in international tax law that focus on (i) the use of soft laws and their acceptance by countries, and (ii) the problems of countries in agreeing to specific tax concepts or allocation of taxing rights, the current international tax developments (including the development of the standard of transparency and exchange of information as well as the BEPS Project) have changed the framework in which the analysis of customary international law in taxation should be addressed. The content of the BEPS Project and its 15 Actions have been decided by the BEPS 44 group (G20, OECD and OECD accession (at that time) countries).

As of March 2020, 137 jurisdictions (136 of the Inclusive Framework and Cyprus of the MLI) are adopting the principal purpose test. The choice for this test by all countries except the United States shows that it will be widely used by countries (developed and developing) to tackle treaty abuse either in bilateral tax treaty negotiations, or in the MLI that modifies bilateral tax treaties. The United States has chosen a detailed LOB with anti-abuse measures to counteract conduit financing.

The use of the principal purpose test (general anti-abuse clause) in a multilateral treaty, and also the commitment of countries belonging to the BEPS Inclusive Framework to implement this test as one of the BEPS 4 Minimum Standards in their current tax treaties and future tax treaties, raises the question of whether the widespread practice of including a principal purpose test in tax treaties is enough to create a customary international tax law rule. Based on the analysis of the objective element (state practice) and subjective element (accepted as law), there are indications that this principal purpose test can be regarded as a principle of customary international tax law. If so, then, the question would be how this principal purpose test can then be interpreted in a way that provides some level of uniformity by countries and some level of certainty for taxpayers.

Taking into account the role of BEPS 44 (developed: OECD and G20 countries) in the development of the BEPS Project the question remains how developing countries (or Global South) will benefit from these developments. If the principal purpose test is a rule of customary international law, what would be the role of developing countries in the development of the rules of customary international law? Further research should be carried out by the International Law Association and/or the UN ILC in the role of the affected states doctrines to ensure that countries in the Global South can also claim their role as states affected by the customary international tax law rule (i.e., the principal purpose test). This approach may also open a door to a more important role of the United Nations and its ILC in the development of BEPS for developing countries.

\footnotetext{
${ }^{126}$ Union of India $v$. Vodafone group, Judgment 7 May 2018, CS(OS) 383/2017\& I.A.No.9460/2017, available at www.italaw. $\mathrm{com} / \mathrm{sites} /$ default/files/case-documents/italaw9701.pdf, at para. 100. This case has also raised other elements of international customary law (i.e. interpretation of a nexus approach by an international arbitration tribunal) which analysis are outside the scope of this contribution. Accordingly, 'The Indian Supreme Court decided the case in Vodafone's favor in January 2012, but shortly after, in March, the Indian government announced surprise retroactive legislative changes, explicitly stating that the term "transfer" includes asset transfers undertaken indirectly through the sale of shares of legal entities. In the arbitration proceedings, Vodafone has argued that CIL governs the case and that under CIL there was no tax nexus in India, and that the retroactive tax amounted to an expropriation. Since the case is in an international arbitration tribunal, CIL could decide the outcome despite the contrary explicit Indian legislation.' See Avi-Yonah, supra note 61, at 11.

${ }^{127} \mathrm{See}$, for the use of the Vienna Convention on the Law of the Treaties, in interpretation of customary international law P. Merkouris, 'Interpreting the Customary Rules on Interpretation', (2017) 19 International Community Law Review 126, available at doi.org/10.1163/18719732-12341350.
} 
Countries have different approaches regarding the role of tax actors (e.g., tax administrations, judges, and taxpayers) and the interpretation of principal purpose test in tax treaties. This can raise problems in the uniform application of the principal purpose test as a minimum standard in international tax law. In some countries, the result could be more uncertainty for taxpayers, or more litigation for tax authorities. Therefore, the analysis of this principal purpose test by international public law, international law, and international tax law experts can contribute to exchange of best practices in the way that customary international tax law emerges but also the limitations and the problems in the interpretation of customary international law with a main focus on the principal purpose test. 